\title{
Editorial: Diversity and inclusion
}

Ian Jenkinson BSC, MBA, CEng, FICE, FIMechE, MCMI

Chairman, Editorial Advisory Panel

When we speak of 'public space' where people move freely to travel, shop, enjoy their leisure and conduct their business it might be assumed that this implies that the public realm is freely accessible to everyone, irrespective of their physical ability or gender. However, after very little investigation it quickly becomes clear that this is a false assumption (Burrage, 2011). For many people the whole structure of the world is an obstacle to their participation. Sometimes it is an obvious barrier such as steps confronting a wheelchair user. More often it is invisible such as uncertainty about kerb heights for a blind pedestrian (Thomas, 2011).

Many countries now have a substantial body of law to prevent discrimination but planning for diversity is a far wider agenda than disability and ageing. The needs of the young and healthy can be as easily overlooked if they are from a social group that is defined as beyond the pale (Andrew, 2011). A diverse population requires a conscious effort to include. Some may argue that this is a social issue, not our business. However this overlooks a key responsibility of the municipal engineer to understand and address the needs of the citizen in the public realm (Cooper and Ashurst, 2011).

It is often said that the world is what we make of it. If those making that world are drawn from a narrow range of gender, ethnic and ability groups then it should be unsurprising if the needs of others are overlooked. The first paper by Hooper (2012) outlines the work that the Institution of Civil Engineers is doing to address this matter. Despite the fact that girls outperform boys in science and maths at school, few women study engineering and even fewer become engineers. It argues that the profession must overcome this imbalance and engage with a wider pool of talented people.

The second paper by Reed and Coates (2012) takes this argument into an international context. The authors argue that while gender in relation to water management has largely been accepted at a policy level it has proved hard to ensure that it is incorporated into the day-to-day work of the engineer. The paper argues that gender issues should be mainstreamed into engineering training and not be regarded as a socioeconomic option on their course. This is not a matter of being 'politically correct'; if a group, in this case women, are identified as the gatekeeper to the proper management of an essential resource then it is essential to ensure that the needs of that group are reflected in the design and maintenance process.

The third paper by Paul (2012) outlines the results of a study, carried out in Pakistan, to find out what would influence more women to enrol in water engineering courses. Despite the small sample surveyed the findings are relevant in showing that gender differences in learning styles should be recognised and that this should influence the teaching styles that are used. This is becoming an issue that many are now identifying as a key consideration in course design and the findings of this paper should be compared to those by Bather (2011) and Mills (2011).

The fourth paper by Andrew (2012) takes the argument about engagement one stage further by pointing out that major projects are delayed because the sponsors fail to obtain community support. The prime argument being that if a project is done 'to' rather than 'with' a community then it is likely that it will be poorly received. The author outlines, in a series of case studies, processes and skills that should enable the engineer to engage better with a community.

Having set the scene, the fifth paper by Bichard and Knight (2012) discusses how inclusion can be facilitated using 'The Great British Toilet Map' as a case study. The authors point out that access to toilet facilities is a critical consideration for many people. Without sure knowledge of accessible toilet facilities many are unwilling to risk travel and thus become trapped in their homes. Societal exclusion is rarely as total as this, or as invisible. To their credit the authors have developed an online map to overcome this issue, but for the map to be reliable it requires more than technology. A culture change by the toilet providers is necessary to ensure access to their data. Municipal professionals should facilitate this.

The sixth paper by Jones et al. (2012) discusses the range of issues that make access to water and sanitation facilities difficult for many poor and low-status users. The illustrations graphically show the difficulties that some users face. The authors argue that small changes in layout can make a significant improvement to the lives of those already marginalised. The paper concludes with the valuable observation that most people will, at some time in their lives, find they suffer 
from similar access problems and that an improvement now is likely to benefit everyone in the future.

The final paper by Gilbertson and Hayes (2012) raises perhaps the most hidden aspect of exclusion, that of fear. Those who are frightened will not venture outside, those with affluence will flee a neighbourhood they consider dangerous, those compelled to stay will fortify their location. The outcome is the breakdown of social relationships and an expansion of fear itself. The authors, citing the riots that occurred across the UK in 2011, summarise the new Ciria publication for community safety. They make a variety of recommendations that underline and amplify many of the points made in earlier papers. A key point being that the interaction and interplay of design factors and societal actors is something that requires wide consultation and careful consideration to understand. This is because the law of unintended consequences can operate with a vengeance.

Perhaps that is the main point to be made in respect to diversity and inclusion. Unless there is a conscious and well considered plan to engage with the wide range and needs of people in society then the outcome is both uncertain and potentially disastrous.

\section{REFERENCES}

Andrew RM (2011) Briefing: Civil engineering to social engineering - Newquay Safe. Proceedings of the Institution of Civil Engineers - Municipal Engineer 164(1): 7-10, http:// dx.doi.org/10.1680/muen.2011.164.1.7.

Andrew RM (2012) 'With' and not 'to' - the key to unlocking communities. Proceedings of the Institution of Civil Engineers - Municipal Engineer 165(3): 149-156, http://dx. doi.org/10.1680/muen.11.00019.

Bather M (2011) Students' views on their education and the future. Proceedings of the Institution of Civil Engineers Municipal Engineer 164(4): 209-219, http://dx.doi.org/10. 1680/muen.2011.164.4.209.

Bichard J-A and Knight G (2012) Improving public services through open data: public toilets. Proceedings of the
Institution of Civil Engineers - Municipal Engineer 165(3): 157-165, http://dx.doi.org/10.1680/muen.12.00017.

Burrage H (2011) Green hubs, social inclusion and community engagement. Proceedings of the Institution of Civil Engineers - Municipal Engineer 164(3):167-174, http://dx. doi.org/10.1680/muen.900030.

Cooper MW and Ashurst J (2011) Future skill sets for the municipal engineer. Proceedings of the Institution of Civil Engineers - Municipal Engineer 164(4): 241-250, http://dx. doi.org/10.1680/muen.2011.164.4.241.

Gilbertson A and Hayes A (2012) Engineering to reduce crime and disorder in public places. Proceedings of the Institution of Civil Engineers - Municipal Engineer 165(3): 175-183, http://dx.doi.org/10.1680/muen.12.00002.

Hooper D (2012) Briefing: The Equality and Diversity Panel, Institution of Civil Engineers. Proceedings of the Institution of Civil Engineers - Municipal Engineer 165(3): 125-126, http://dx.doi.org/10.1680/muen.12.00034.

Jones H, Fisher J and Reed R (2012) Water and sanitation for all in low-income countries. Proceedings of the Institution of Civil Engineers - Municipal Engineer 165(3): 167-174, http://dx.doi.org/10.1680/muen.12.00018.

Mills PJ (2011) Civil engineering degrees: fit for the future? Proceedings of the Institution of Civil Engineers - Municipal Engineer 164(4): 221-228, http://dx.doi.org/10.1680/muen. 2011.164.4.221.

Paul P (2012) An analysis of gender when creating a water engineering course. Proceedings of the Institution of Civil Engineers - Municipal Engineer 165(3): 137-147, http://dx. doi.org/10.1680/muen.12.00020.

Reed B and Coates S (2012) Diversity training for engineers: making 'gender' relevant. Proceedings of the Institution of Civil Engineers - Municipal Engineer 165(3): 127-135, http://dx.doi.org/10.1680/muen.11.00020.

Thomas C (2011) Briefing: Minimum effective kerb height for blind and partially sighted people. Proceedings of the Institution of Civil Engineers - Municipal Engineer 164(1): 11-13, http://dx.doi.org/10.1680/muen. 1000005 . 